\title{
Correction to: Impact of orthogeriatric management on the average length of stay of patients aged over seventy five years admitted to hospital after hip fractures
}

\author{
Pierre-Sylvain Marcheix ${ }^{1}$ Camille Collin ${ }^{1}$ - Jérémy Hardy ${ }^{1} \cdot$ Christian Mabit $^{1} \cdot$ Achille Tchalla $^{2}$. \\ Jean-Louis Charissoux ${ }^{1}$
}

Published online: 4 February 2021

(C) SICOT aisbl 2021

\section{Correction to: International Orthopaedics} https://doi.org/10.1007/s00264-020-04908-z

The article "Impact of orthogeriatric management on the average length of stay of patients aged over seventy five years admitted to hospital after hip fractures", written by PierreSylvain Marcheix, Camille Collin, Jérémy Hardy, Christian Mabit, Achille Tchalla and Jean-Louis Charissoux, was originally published Online First with Open Access under a Creative Commons Attribution (CC BY) licence 4.0. After publication, the author(s) decided to cancel Open Access. Therefore, the copyright of the article has been changed to (C) SICOT aisbl 2021 with all rights reserved.

The original article has been corrected.

The online version of the original article can be found at https://doi.org/ 10.1007/s00264-020-04908-Z

Pierre-Sylvain Marcheix

psmarcheix@orange.fr

1 Department of Orthopedics-Traumatology, CHU Dupuytren, 2, Avenue Martin Luther King, 87042 Limoges Cedex, France

2 Department of GeriatricMedicine, Dupuytren University Hospital, 2, Avenue Martin Luther King, 87042 Limoges Cedex, France 